\title{
Kindergarten and School Social Assistance During the COVID-19 Pandemic in Hungary
}

\author{
ANDREA HOMOKI \\ Affiliation: Gál Ferenc University \\ Faculty of Health and Social Sciences, Gyula, Hungary \\ Email: andi.homoki@gmail.com \\ KRISTÓF CZINDERI \\ Affiliation: Gál Ferenc University \\ Faculty of Health and Social Sciences, Gyula, Hungary \\ Email: kczinderi@gmail.com
}

\begin{abstract}
In this paper, we have analyzed the results obtained in the third year of our longitudinal research (2018-2020) regarding the work of kindergarten and school social workers, research conducted in connection with the Hungarian Educational Research Association. The service provided by kindergarten and school social workers was made generally available in Hungary by a legislation change implemented in 2018. By the end of the school year 2018/2019, after initial difficulties, we noticed a positive change in the supportive attitude and acceptance of teachers and public educational institutions towards the work of kindergarten and school social workers. We confirmed an increase in connections to fellow professions as well as in the level of mutual initiative (Homoki \& Czinderi, 2020). The continuous development of the service and the reinforcement of professionals is essential as there is a high degree of fluctuation at the national level (Sinka, 2019), even more increased by the effects of the COVID-19 pandemic, posing unprecedented challenges for actors in public educational institutions. Based on our qualitative data obtained by a focus group interview, we have shown how social workers in different types of settlements and educational institutions of the country $(N=13)$ were able to adapt to the crisis. What was the degree of fluctuation? What kind of challenges did they face, and what types of resources were they able to mobilize during the online education in the first and second waves of the pandemic? Our data show a shift in priorities at the individual, group, and community levels of social work.
\end{abstract}

Keywords: kindergarten and school social workers, online education, pandemic, professional resources, flexibility 


\section{Introduction}

In September 2018, kindergarten and school social services were introduced in public education institutions in Hungary on a normative basis. Prior to the change in legislation', local governments were able to operate this new form of social assistance service in a three-year pilot program. In this study, we present the results obtained in the third year of our longitudinal research (2019-2021) ${ }^{2}$ focusing on the work of kindergarten and school social workers. The explorative research regarding the characteristics of the activities of the professionals providing the social assistance service introduced in September 2018, as well as the satisfaction survey and needs assessment of the co-professions and stakeholders related to the service were carried out half a year and one year after the introduction of the service, respectively. By the end of the school year 2018/2019, after the initial difficulties, we observed a clear change in the supportive and accepting attitude of teachers and public education institutions in relation to the activities of kindergarten and school social workers. The results confirmed an increase in the openness to fellow professions, as well as in the level of mutual initiative. We also found that from an organizational point of view, social helpers were operating in an ambiguous position, being "insiders" and "outsiders" in educational institutions at the same time. However, they showed a high degree of resilience, flexibility, and commitment to leaving their comfort zone while managing their schedules, responsibilities, and critical remarks regarding their work (Homoki \& Czinderi, 2020).

Continuous development of the service and provision of professional reinforcement is essential (Sinka, 2019), as our results show that the fluctuation was high nationwide one year after the introduction, and the number of vacancies was almost $40 \%$ of all positions. The training and employment of well-trained, system-oriented, creative, innovative, socially sensitive, needs-oriented helpers constantly adaptable to change is a challenge for the high-quality implementation of kindergarten and school social work across the country.

Whether we look at the situation of social workers from the point of view of training, application or working conditions, the conditions of institutional education and training changed significantly during the COVID-19 pandemic period. Therefore, in the third phase of our research we examined the adaptation of social workers to the emergency situation

1 15/1998. (IV. 30.) NM (Ministry of Social Affairs) decree on the professional tasks of child welfare and child protection institutions and persons providing personal care and the conditions of their operation (25-26. §).

${ }^{2}$ Our research conducted at the Gál Ferenc University, Faculty of Health and Social Sciences, Department of Social Work is connected to HERA's (Hungarian Educational Research Association) Children and Youth at Risk and Social Pedagogy Network. 
declared during the pandemic using qualitative methods in different settlements (capital, county capitals, small towns, villages) and types of institutions in an online professional workshop $(\mathrm{N}=10)$. We sought answers to the challenges faced during the distance teaching and online education period. Our goal was to explore the human and professional resources mobilized by social helpers in the first and second waves of the pandemic, which strengthened their professional skills and resilience and led them to innovative, new ways of solving tasks.

\section{Starting points and frameworks of social assistance in kindergartens and schools}

Both internationally and in Hungary, the examined complex child protection service has a solid scientific background dating back several decades. This service is a professional assistance in kindergartens, schools and dormitories, and it is included in the general child protection subsystem. "It can contribute to improving the daily lives of children, teenagers, young people, students in kindergarten, school, dormitory community, home or residence, holidays" (Budai, 2020, p. 8). As a result, in addition to children, other actors of the institutions (teachers, families) can employ strategies to reduce social problems and avoid serious crises, traumas and conflict situations during preventive programs. Helpers with a complex child protection task at schools have a particularly important social and economic role in reducing school dropout, thereby promoting labor market integration, independently of the social status of children's families (Bányai, 2020). Through ordinary support activities and targeted interventions, professionals become able to stop the gradual withdrawal, which results in school dropout, by recognizing early signs. In addition to the importance of recognizing warning signs, Bányai mentions individual, special forms of support and programs that can be successful, but also emphasizes purposeful, well-thought-out and planned outreach activities that can effectively prevent and reverse dropout, a process that may last for generations. With professional help, a young person can be transferred to the higher levels of the public education institution system successfully, and with the competence- and attitude-shaping effect of inclusive programs, these young people can finally be successfully integrated into the labor market.

In order to achieve its professional goals, the professional must know the school child protection and school social work models that provide a starting point in the development and application of innovative individual, group and community social work tools that are organically adapted to the local characteristics of the institutions. In 50 countries around the world, school social work can be traced back a century. 
The theoretical models preparing the international professional protocol (1994) were developed in the second half of the $20^{\text {th }}$ century (Allen-Meares et al., 1986; Allen-Meares, 2010; Costin, 1975). The starting point of the Hungarian models with a modern human-ecosystem approach based on these models is the relational system between the individual and society. Hungarian models, in addition to the diversity of tasks, put emphasis on the professional skills and professional competence (Dávid et al., 2008; Gergál \& Máté, 2009; Máté \& Gergál, 2020; Soós, 2018). The precondition for a service that meets individual and community needs is that social workers, either with social or pedagogical qualifications (or both), are able to meet the legal and professional expectations and have the professional skills required for their job (Homoki, 2019; V. Gönczi, 2018).

In our previous study (Homoki \& Czinderi, 2020), we wrote about the initial difficulties and dilemmas following the launch of the service. Right in the beginning, the social helpers had to face the need to define a framework for cooperation, through the steps of acceptance-inclusion-constructive cooperation, during the implementation of their preventive or corrective activities in Hungarian public educational institutions. "Complex and dynamic postmodern ecological models" draw attention to the importance of the "bridge role," that is, building on the strengths of helpers and their environment, as well as on the development of child and community resilience (Homoki, 2016). These models also increasingly emphasize the need for inter-professional cooperation, institutionalization and networking (Bányai, 2000; Homoki, 2010; Soós, 2017).

Budai (2020), in his clear and logical synthesis of the global definition of social work (International Federation of Social Workers, 2014) and international school social work definitions, also emphasizes the observance of competence limits and the need to operate inter- and multiprofessional teams during both pedagogic and social work.

According to the development of the international history of school social work, Hungary is almost a century behind, which, after a review of the literature, can be best seen in the differences in the applied methods and the focuses of the system. In Hungary, the institutional development and consolidation of the current service is still an ongoing process, while in the United States of America, which can be considered the cradle of school social work, we can read about the effectiveness of programs organized in the primary prevention phase reflecting the real needs of certain age groups (Dupper, 2002; Loue, 2018). 
In Hungary, the objectives of the decree that sets the framework for the kindergarten and school social assistance system-in line with the human ecological approach-include:

- Bring families and children closer to each other.

- Instead of the controlling, sanctioning, punishing, labelling function related to the classical interpretation of social work, support the helping activities that show a positive direction and a path for development out of problematic situations.

- In the processes of reciprocity and retroactivity that determine the life of the institution, it helps to respect the interests and rights of all actors and to create a non-violent school environment through the preventive work of the school social worker.

- The professional should work with the tools of social help, and delegate "official and law enforcement" tasks to representatives of the relevant fellow professions (e.g., school police) (Budai, 2020).

In the light of the literature and research results on the topic, it is clearly seen that kindergarten and school social helpers ("school social workers" in international terminology) have a largely diverse set of tasks, which are, in the framework of psychoeducation and in cooperation with other professions, as follows:

- constructive conflict management,

- reduction of prejudices,

- development of individual skills, abilities,

- development of social skills, abilities,

- sociability,

- development of resilience.

At the current stage of our research, we sought to answer the question of how the empowering tasks at the individual, community and institutional level, affecting directors, teachers, parents and children, were performed during the COVID-19 pandemic, an event that radically changed the economic, political, cultural and social conditions at the $8^{\text {th }}$ level of the human ecosystem ( $\mathrm{global}$, ecological level), also transforming the social, cultural and ordinary way of life of individuals and families. 


\section{Previous research}

In the first two stages of the longitudinal research, we explored the experiences, remarks and dilemmas of the responding school participants about the everyday practice of kindergarten and school social assistance by means of focus group interviews and statistical data analysis. Among the respondent institutions (in Békés county), all levels of public education institutions appeared, from kindergartens to secondary schools. Representatives were delegated by the heads of institutions that were located in different types of settlements. The number of socially disadvantaged children in the surveyed institutions typically varied between $10-20 \%$.

\section{Results of the first stage (half a year after launch)}

Our results, revealed by metaphor analysis and interview methods, show that after the launch of the new system in 2018, the arrival of the new professionals was received with great anticipation in all types of institutions; however, half a year after the introduction, the responses reflected ambivalent feelings. Factors that limited the chance of success, such as the framework of the service, the personality and professional knowledge of the service provider were already noticed; at the same time, good practices of providing efficient support for children's development as a result of successfully implemented cooperation also emerged.

The majority of respondents on the Holtartóméter ("Where are we at?-meter") scale used in the focus group interview gave responses indicating slow start and moderate progress in the first stage.

\section{Results of the second stage (one year after launch)}

In the light of the results of the research, the development of the service and ensuring the continuity of professional training in the field is of great importance, especially with regard to the high degree of fluctuation that was detected at the national level in the first year.

The social helpers recognized that one of the important factors in the quality development of the service is effective communication with parents, students, teachers, maintainers, the local community, as typically stakeholders had too little information about the service.

The key to success is to make the service and the service provider visible, to bring problems to the surface, during which trust can be built and the authenticity of the social worker can be enhanced It also lays the foundation for common thinking, action plans and strategies, and provides the important possibility to collect feedback on results at the individual, managerial and community levels as well. 
As is true of any field of social work and help with a system approach, it seems to be proven here as well that "one cannot do alone": the important, seemingly small but sometimes huge results can only be achieved with extensive professional support and cooperation; and they have a positive preventive effect on their community during a circumstantial event.

By the end of the first year, a change of attitude could be detected in relation to the supportive, accepting attitude of teachers and public education institutions in relation to the activities of kindergarten and school social workers. The results confirm the new social helpers' openness to co-professions and an increase in the level of mutual initiative. Despite the fact that, from an organizational point of view, social helpers are operating in an ambiguous position, being "insiders" and "outsiders" in educational institutions at the same time, they show a high degree of resilience, flexibility, and commitment to leaving their comfort zone while managing their schedules, responsibilities, and critical remarks regarding their work.

\section{The third stage of the research}

\section{Methods}

The methodological bases of the research were determined from the traditional, sociological approaches and practices of social science research-taking into account the examined segment of social work-according to the new methodological guidelines of social work research.

Social work research ... is inseparable from the problem areas of social work, problemsolving processes, evaluation and social programs, the development of services. Just as the field itself is transdisciplinary, which means it merges various theoretical areas and even practice with the goal of problem solving, thus social work research is also transdisciplinary, both in its approach and in its methods ... are about the world we live in, the difficulties and the outcomes we see every day. Thus, research will indeed help practical work, and this new experience may even lead to a much closer relationship between the two areas, practice and research. (Fábián, Hegyesi, \& Talyigás, 2021, p. 1)

In addition to the skills of interpreting macro-level social changes, using the research methods of social work, it was our goal at different stages of the longitudinal study to analyze social cultures: lifestyles (Wessely, 2003), communication patterns and habits in organizational cultures, community relations, group dynamics, personal life paths with a recursive effect on a professional's identity, as seen in the drafts for the focus 
group interview and professional workshop in Annexes no. 1-3. In this study, we aimed to explore the specifics of the new child welfare service during the COVID-19 pandemic period in our small-sample qualitative research. It was an exciting question for us how a service that is still evolving works in the period of a pandemic; obviously requiring a high degree of creativity and flexibility from professionals while the framework, rules of work and social distancing have led to a complete transformation of circumstances.

During the sampling procedure, the Great Regions of Hungary (Annex 4) provided the starting point.

The European Parliament and the Council have established the NUTS 1 level in Hungary in accordance with the provisions of Regulation (EC) No 1059/2003, which corresponds to the so-called "statistical large regions." Hungary was divided into three major statistical regions: the Great Plain and the North, Transdanubia and Central Hungary. (KSH 2016)

In the first round of the sampling procedure, the three counties that covered one NUTS-1 region each were selected. In the counties nominated, we selected the methodological institutions published in the first round of the sampling procedure on the basis of the County Child Welfare Address List of the National Association of Hungarian Family Support and Child Welfare Services $(N=25)$. When contacting the methodological centers, the objective was for the leaders to delegate micro-collectives for qualitative research, working in different types of settlements (village, small town, county seat, capital) and different types of institutions (kindergarten, primary and secondary education, institution, college).

Based on the results of the previous stages of our research, we predicted further vigorous development in the next stage of our research plan. However, the COVID-19 pandemic forced a general transformation of the framework and opportunities of kindergarten and school social assistance. In this changed situation, we examined how their work has changed in different regions of Hungary, how needs have changed, and how old / new kindergarten and school child protection professionals who had already successfully overcome the initial difficulties have managed to meet the new challenges. Experts from different regions of the country were invited to the professional workshop ${ }^{3}(\mathrm{~N}=13)$ and data were collected by various

3 The authors would like to express their sincere appreciation to Kata Szabó, a social work student at Gál Ferenc University, Faculty of Health and Social Sciences, for her help in the transcription of the interviews. 
gamification and abstraction methods, metaphor analysis, world-café method, regarding the following topics:

- their general well-being, feelings and state of health

- their motivations

- their work-related feelings

- their results

- their difficulties

- innovative solutions for adaptation to the pandemic

- cooperation, fluctuation

- their evaluation of the present situation

- their individual and professional vision

\section{Results}

Respondents volunteered for the research and were very active throughout, arriving "curiously, openly, curiously, enthusiastically, cheerfully" and hoping to return to work with useful knowledge as a result of putting heads together with their peers working in more distant parts of the country. This hopeful anticipation also manifested itself among colleagues who, based on their answers to the first question, arrived to the online session "nervously and terribly tired." This is indicated by the pictorial metaphors with which they expressed their expectations. "What would you take home?" Based on the following quoted answers, it is clear that in addition to interest, they expected concrete practical knowledge, facts and experience that they can adapt in their everyday lives and inspiration: "A bowl of cookies; instructions for use; sun; fire; an apple from the tree of knowledge; a golden apple; a calm water mirror; a suitcase; keys."

In the light of our previous research results, professional self-determination and identity are of paramount importance for effectiveness. We examined how they define themselves as professionals at this third stage of the research as well. We asked them to complete the following sentence: "I am a kindergarten, school helper, who (is)..." We got a more nuanced picture of the professional self with this abstraction technique. 


\section{Table 1: Expression of professional identity}

I am a kindergarten, school social helper, who (is)...
$\begin{array}{ll}\text { a student } & \text { delights in the return of children } \\ \text { a rope dancer } & \begin{array}{l}\text { struggles } \\ \text { the Great Hohoho Angler }\end{array} \\ \text { between systems } & \text { has got to be welcomed by the children } \\ \text { whispering with children } & \text { strives to be present, always renewed } \\ \text { bunch of grapes } & \\ \text { willow } & \\ \text { clock } & \\ \text { open door } & \end{array}$

${ }^{4}$ A well-known Hungarian cartoon character from the 1980 s.

The topics of struggle, the willingness to constantly innovate, openness and balance, and the role of the bridge in classical theories of school social work are represented among the answers (see Table 1).

We asked them to recall their activities during the pandemic using the keywords "pandemic - workplace (families-children) - social assistance." Our research questions included, "What feelings did they struggle with, who surrounded them? What difficulties did they have to deal with?"; and retrospectively, "What is good to remember? How has work changed in the last year? What did they do differently? What needs have emerged? How could they stand their ground? Were there any colleagues who left?"

After analyzing the narratives engendered by the above questions, we came to the conclusion that the way in which kindergarten and school social assistance continued in different settlements of the country during the pandemic period shows a high degree of heterogeneity. The legislative changes during the declared emergency, in theory, only affected the working conditions of kindergarten and school workers, but not their position. However, there were some settlements where the head of the social institution deployed social helpers to another sector (e.g. elderly homes) and suspended their activity conducted in educational institutions altogether, using school and kindergarten closures as an explanation. This caused a serious break in their developing activities and professional relationships as well as in their building of trust, evolving relationship and regular contact with the children. Interestingly, the great sadness and bitterness due to this change among the 
professionals affected by redeployment caused such a remarkable mental imprint that it was also noticeable in their answers to the above questions regarding professional identity. In the period of reopening of schools after COVID restrictions have been lifted, they feel like starting over as a professional, less energized, more nervous, insecure and burdensome.

However, we found that in some places there was a completely different approach to the situation caused by the pandemic. In these cases, despite the distance and the lack of physical contact, kindergarten and school social helpers kept helping children (who were playing and studying at home with their families during the pandemic) and teachers, experimenting with and finding new and innovative solutions, assessing the changes of needs. According to their account of the recent period, they did not feel less but more, and they have been able to be strengthened in their professionalism. Based on their answers, the key elements of the development process resulting from successful adaptation can be identified as follows:

- multi team (task group of professional helpers with various qualifications in the same field)

- support work transferred to online space-flexibility

- more structured operation, well-defined frameworks

- development of a new methodology

- internal trainings (conscious use of the benefits of interprofessional and multi team)

- strengthening interdependence with online community experiences (case studies, weekly online café, nurturing relationships, organizing a professional week)

- involvement of volunteers, NGOs, resource allocation

- online group organization (for parents, children and employees of public education institutions)

- design and sharing an online service catalogue on professional platforms, online classroom classes, and parent groups

To provide a more detailed overview of the results of our qualitative research, we present the most important aspects in a table (see Table 2) where we organized our results according to five research focuses (as seen in the rows of the table), naming the related dilemmas and attributes. We illustrate each of them with quotes from the interviews. 


\section{Table 2: Results organized by focuses / question groups of the research}

\begin{tabular}{|c|c|c|c|}
\hline $\begin{array}{l}\text { Research focus, } \\
\text { question group }\end{array}$ & Dilemma & Attributes & $\begin{array}{l}\text { Professional experiences / Good practices } \\
\text { (quotes from the interviews) }\end{array}$ \\
\hline $\begin{array}{l}\text { The effect of } \\
\text { the relationship } \\
\text { with the school } \\
\text { management } \\
\text { and teachers } \\
\text { on the orga- }\end{array}$ & $\begin{array}{l}\text { Possibility } \\
\text { of presence }\end{array}$ & $\begin{array}{l}\text { Integration- } \\
\text { Fluctuation }\end{array}$ & $\begin{array}{l}\text { "There are schools where we are greeted with } \\
\text { open arms because there are a lot of prob- } \\
\text { lematic situations whereteachers have been } \\
\text { alone so far because there was no help, } \\
\text { and now they have finally got some help } \\
\text { to which they are strongly attached." }\end{array}$ \\
\hline
\end{tabular}

nizational

integration?

$\begin{array}{ll}\text { Practice } & \text { Helping Authenticity } \\ \text { of helpers' } & \text { profession, } \\ \text { functions } & \text { professional } \\ \text { in public } & \text { identity, } \\ \text { educational } & \text { credo } \\ \text { institutions? } & \end{array}$

"There are a lot of topics... to be cut out. Leave only the ones in which one can appear well and competently, in which one can undertake and accomplish. You don't have to take on everything because no one understands everything and that will suggest inauthenticity. Every helper has their own specialty that they need to find. Every school is different, so the atmosphere is different, which is not striking if the school's social assistance program is different."

$\begin{array}{lll}\begin{array}{lll}\text { Professional } \\ \text { and inter- }\end{array} & \begin{array}{l}\text { Novelty }- \\ \text { Resistance }\end{array} & \text { Privation } \\ \text { professional } & & \begin{array}{l}\text { Need- } \\ \text { oriented } \\ \text { cooperation? }\end{array} \\ & & \begin{array}{l}\text { approach } \\ \end{array}\end{array}$

\footnotetext{
"People think that the system will expose the problematic children who have not surfaced so far." "I don't see much resistance from teachers and, in fact, I think teachers would need a social approach as they deal with a lot of issues and they are pretty much alone in this situation. There is no supervision of teachers and the burnout of teachers could be addressed by the social professionals."

"Where we can't intervene, we call fellow professions, that's another type of mood and opportunity. Another very important thing is when a teacher sends a note about a problematic child, they get into the system and nothing happens to them. I say it in this ugly way to make you feel its weight. The teachers don't send a note because they think 'he won't even get to a psychologist anyway' because it is just the reality. They will be able to see a psychologist in like half a year and they will either no longer be in crisis or they will be in a much bigger crisis. The problem is that this makes the recommendation of the service inauthentic."
} 


\begin{tabular}{|c|c|c|c|}
\hline $\begin{array}{l}\text { How to } \\
\text { measure } \\
\text { success? }\end{array}$ & $\begin{array}{l}\text { New } \\
\text { contents } \\
\text { and } \\
\text { methods } \\
\text { Reorga- } \\
\text { nization of } \\
\text { time and } \\
\text { space }\end{array}$ & $\begin{array}{l}\text { Interactivity, } \\
\text { Interpersonal } \\
\text { relations }\end{array}$ & $\begin{array}{l}\text { "I was very happy that the teacher asked me } \\
\text { to introduce myself in some playful way } \\
\text { because I had a problematic kid in the class } \\
\text { and I didn't go to him for the first time, but } \\
\text { I dealt with the community in the first place } \\
\text { for a } 45 \text { minute time. They also introduced } \\
\text { themselves, followed by a face-to-face con- } \\
\text { versation with the child, and I have been } \\
\text { helping him with the right methods ever } \\
\text { since." "...kids love the activities where they } \\
\text { don't have to just sit in class." }\end{array}$ \\
\hline $\begin{array}{l}\text { Feedback } \\
\text { method, } \\
\text { frequency, } \\
\text { forming effect, } \\
\text { feedback of } \\
\text { results? }\end{array}$ & $\begin{array}{l}\text { Communi- } \\
\text { cation } \\
\text { patterns }\end{array}$ & $\begin{array}{l}\text { Efficiency } \\
\text { increase } \\
\text { Open com- } \\
\text { munication }\end{array}$ & $\begin{array}{l}\text { "Communication is lacking, that's where the } \\
\text { whole thing is slipping away." } \\
\text { "Professional development feels different in } \\
\text { different institutions." } \\
\text { "Sharing experiences and good practices, both } \\
\text { inside and outside the school, is very im- } \\
\text { portant and it promotes embedding of the } \\
\text { helpers in the school's community." }\end{array}$ \\
\hline
\end{tabular}

\section{Summary}

The future is open, and everyone

-yes, each one of us-

co-decides about it. (Wolfgang G. Sonnenburg)

Credibility, strength, and openness largely determine the success of professional work with children and their educators. In the crisis caused by the pandemic, and potentially in the years to come, while social workers are expected to remain under a high degree of mental strain, the supportive power of professional teams (multi- and interprofessional groups) has become even more important. In addition to professional support from managers and employees, the confirmatory, reinforcing social support effect of personality and proximity is an important burn-out prevention factor. The responses show the perseverance of human helpers, with the respondents perceiving a decrease in the degree of fluctuation in their workplaces during this difficult period. In order to benefit from the heterogeneity of the conditions of kindergarten and school social service and its quantitative and qualitative indicators in the coming years, the need and necessity of networking was formulated by social workers working in the same field, but with different depth and scope of social and educational situations. Educational institutions, practical training sites and practical partner institutions can play an important role in this. Perceiving the complexity of the provided service, kindergarten and school social workers expect guidance not only from professional governing organizations, but also from the study opportunities offered by higher education institutions. 


\section{References}

Allen-Meares, P. (2010). Social work services in schools (6 ${ }^{\text {th }}$ ed.). Pearson.

Allen-Meares, P., Washington, R. O., \& Welsh, B. L. (1986). Social work services in schools. Prentice-Hall.

Bányai, E. (2000). Az iskolai szociális munka és lehetőségei az ezredfordulón Magyarországon. Háló, 5(8), 3-5.

Bányai, E. (2020). A korai iskolaelhagyás megelőzése a szociális munka eszközeivel. Szociálpedagógia (16), 31-45.

Budai, I. (2020). Az iskolai szociális munka (segítés) egyetemes paraméterei. Szociálpedagógia (16), 7-29.

Costin, L. B. (1975). School social work practice: A new model. Social Work, 20(2), 135-139.

Dávid, M., Estefánné, M. V., Farkas, Z., Hídvégi, M., \& Lukács, I. (2008). Hatékony tanulómegismerési technikák. Educatio Társadalmi Szolgáltató Közhasznú Társaság.

Dupper, D. R. (2002). School social work: Skills and interventions for effective practice. John Wiley \& Sons, Inc.

Fábián, G., Hegyesi, G., \& Talyigás, K. (2021). Előszó. In G. Fábián, \& G. Hegyesi (Eds.), A szociális munka elmélete és gyakorlata (Vol. 7, pp. 1-5). MTA Szociológiai Tudományos Bizottság Szociális Munka Albizottság.

Gergál, T., \& Máté, Z. (2009). Az iskolai szociális munka lehetőségei: a pécsi modell. In Z. Máté, \& J. Szemelyácz (Eds.), Az iskolai szociális munka kézikönyve (pp. 81-98). INDIT Közalapítvány.

Homoki, A. (2010). Child care's dilemmas in the primary schools. Practice and Theory in Systems of Education, 5(4), 321-330.

Homoki, A. (2016). Gyermekvédelemben élni a Szeretet erejével: A boldogulás elősegítése nehéz helyzetben lévő serdülők körében. Áldott Remény Könyvkiadó.

Homoki, A. (2019). A gyermekvédelmi szükségletorientáció az óvodai, iskolai segítésben. Deliberationes, XII(1), 43-71.

Homoki, A., \& Czinderi, K. (2020). Óvodai és iskolai szociális segítők beágyazódása a köznevelési intézmények szervezeti kultúrájába. In A. Varga, H. Andl, \& Z. MolnárKovács (Eds.), Új kutatások a neveléstudományokban 2019 (Vol. I, pp. 47-57). MTA Pedagógiai Tudományos Bizottság; PTE BTK Neveléstudományi Intézet. https://nevtud.btk.pte.hu/sites/nevtud.btk.pte.hu/files/files/ukn2019magyar.pdf

International Federation of Social Workers. (2014). Global definition of social work. Retrieved May 28, 2021, from https://www.ifsw.org/what-is-social-work/globaldefinition-of-social-work/

Loue, S. (2018). Legal issues in social work practice and research. Springer International Publishing.

Máté, Z., \& Gergál, T. (2020). Az iskolai szociális munka gyakorlata. A prevenciós munkáról. Szociálpedagógia (16), 147-171.

Sinka, E. (2019). Bevezető-Alapvetések. In M. Csillag, \& Z. Palotás (Eds.), Útmutató az óvodai és iskolai szociális segítő tevékenység bevezetéséhez és gyakorlatához az iskolában (pp. 5-9). Oktatási Hivatal.

Soós, Z. (2017). Szociális ismeretek oktatása a pedagógus BA képzésekben. Szociálpedagógia (3-4), 24-39.

Soós, Z. (2018). Szerkesztői előszó. Szociálpedagógia (12), 5-7.

V. Gönczi, I. (2018). Határok mentén. Szociálpedagógiai szemlélet a pedagógusképzés tükrében. Szociálpedagógia (12), 96-108.

Wessely, A. (2003). A kultúra szociológiája. Osiris. 


\section{Appendices}

\section{Appendix 1}

Focus group interview guide (for teachers, kindergarten / school social workers, school child protectors, teacher or social worker candidates, parents)

I. Presence and activity of educational personnel in the institution Introductory questions:

"Assistance in school and/or Home school. Being home at school."

What does this mean for you? How do you interpret that? What forms of help do appear in your institution? (moderator notes the status of professionals mentioned by participants)

II. Metaphor analysis:

Please complete the following sentences according to your feelings, experience, opinion: (we provide a blank sheet and a writing instrument, sample in Appendix 2)

Please list all helpers mentioned by the participants, insert them in a sentence, for example: A school psychologist is like...

III. Helping in kindergartens and schools (what does it mean, how did it start, first experiences) Keywords: goal, scope of activity, organizational connection, position, cooperation

How did the helpers' presence start in the institution? How was the first meeting with different actors at the school? What were their primary goals? How do they work in everyday life? Who did they establish connections with? In what situations was their help requested? In what situations do they count on their help? How was the cooperation implemented? Has there been any feedback? Are there any measurable results? How was the feedback done?

\section{Vision}

How is this new kind of service embedded in the world of kindergartens and schools?

V. "Where-are-we-at-meter" projection

Participants get a sheet with the following figure. They are asked to mark the current progress of the system's development, according to their opinion.

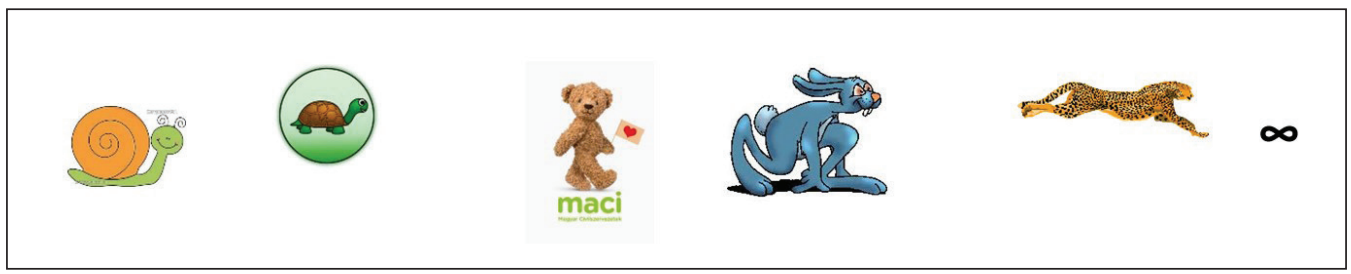




\section{Appendix 2}

Metaphor analysis

Please finish the sentences dictated by the moderator!

1.

2.

3.

4.

5.

Thank you for your answers, please return the page to the moderator!

\section{Appendix 3}

Plan for the professional workshop (2 hours / 120 minutes)

1. Greetings (5 minutes)

Who are we? "I came from America, the coat of arms of my profession is..." (Note: reference to a children's game popular in Hungary since the 1960s, '70s where a participant has to describe a chosen profession using a description or sign language and other participants have to find out which profession it is.)

Brief talk about the antecedents and preliminary results of the research. What do I expect from today's meeting?

(Get to know each other, place ourselves loosely and playfully in time)

2. Introduction (25 minutes)

Only first name and a personal trait or feeling that describes me

With symbols, pictures "When you think that..."

How are you? (general well-being, condition, feelings)

What did you bring with you? (preparation, motivation)

What would you like to take home from here? What comes to your mind?

3. Think about your job, and finish the sentence (15 minutes)

\section{Before...}

I am a school and kindergarten social worker who...

I achieved

4. Time travel (25 minutes)

We go back in time, space, we can turn into fairytale witches, wizards, fairies, shamans-everyone decides who/what... 
"Get your magic ball!"

Instruction: Now tell the following words to your magic ball:

Pandemic, workplace (family / child), social assistance (wait a few minutes and look into your magic ball...) What do you see, please tell me! What is this picture like? Where are you? How do you feel? Who surrounds you? What is difficult? What is good to see and feel?

5. World-café (40 minutes)

E.g. How has work changed in the last year? What do you do differently? What kind of needs have emerged? How did you know you were able to stand up? Were there any colleagues who quit? What are you proud of?-other related open issues.

Let's summarize what we know today about kindergarten and school social workers and help.

\section{Closure (10 minutes)}

Get your magic ball again and let's travel to the future, to 2022.

Where are you, how do you feel, how do you work? What do you consider the most important, what do you like the most about your job?

\section{Appendix 4}

NUTS-1 regions in Hungary

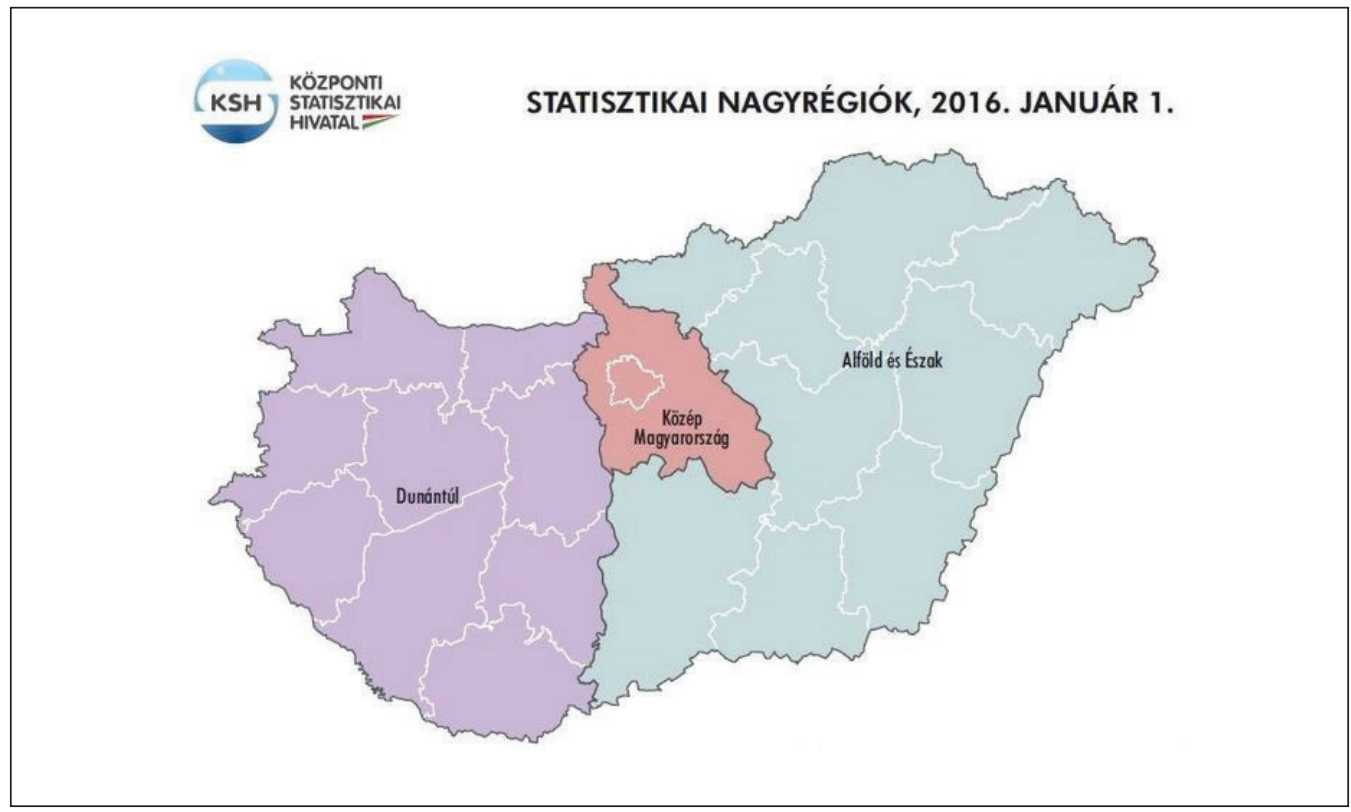

Source: https://hunmix.hu/nagyregiok/ 